Article

\title{
Impact of the Simulated Gastric Digestion Methodology on the In Vitro Intestinal Proteolysis and Lipolysis of Emulsion Gels
}

\author{
Camila Mella $^{1}$, Michelle Quilaqueo ${ }^{2}$, Rommy N. Zúñiga ${ }^{3,4}(\mathbb{D})$ and Elizabeth Troncoso ${ }^{2,4, *(D)}$ \\ 1 Department of Food Science and Chemical Technology, Universidad de Chile, Santos Dumont 964, \\ Independencia, Santiago 8380494, Chile; c.mellac@utem.cl \\ 2 Department of Chemistry, Universidad Tecnológica Metropolitana, Las Palmeras 3360, Nuñoa, \\ Santiago 7800003, Chile; michelle.quilaqueo@amtc.cl \\ 3 Department of Biotechnology, Universidad Tecnológica Metropolitana, Las Palmeras 3360, Nuñoa, \\ Santiago 7800003, Chile; rommy.zuniga@utem.cl \\ 4 Programa Institucional de Fomento a la Investigación, Desarrollo e Innovación, Universidad Tecnológica \\ Metropolitana, Ignacio Valdivieso 2409, San Joaquín, Santiago 8940577, Chile \\ * Correspondence: elizabeth.troncoso@utem.cl
}

check for updates

Citation: Mella, C.; Quilaqueo, M.; Zúñiga, R.N.; Troncoso, E. Impact of the Simulated Gastric Digestion Methodology on the In Vitro Intestinal Proteolysis and Lipolysis of Emulsion Gels. Foods 2021, 10, 321. https://doi.org/10.3390/foods 10020321

Academic Editor: Maria D. Guillen Received: 30 December 2020

Accepted: 29 January 2021

Published: 3 February 202

Publisher's Note: MDPI stays neutral with regard to jurisdictional claims in published maps and institutional affiliations.

Copyright: (C) 2021 by the authors Licensee MDPI, Basel, Switzerland. This article is an open access article distributed under the terms and conditions of the Creative Commons Attribution (CC BY) license (https:// creativecommons.org/licenses/by/ $4.0 /)$

\begin{abstract}
The aim of this work was to study the impact of the methodology of in vitro gastric digestion (i.e., in terms of motility exerted and presence of gastric emptying) and gel structure on the degree of intestinal proteolysis and lipolysis of emulsion gels stabilized by whey protein isolate. Emulsions were prepared at $\mathrm{pH} 4.0$ and 7.0 using two homogenization pressures (500 and 1000 bar) and then the emulsions were gelled by heat treatment. These gels were characterized in terms of texture analysis, and then were subjected to one of the following gastric digestion methods: in vitro mechanical gastric system (IMGS) or in vitro gastric digestion in a stirred beaker (SBg). After gastric digestion, the samples were subjected to in vitro intestinal digestion in a stirred beaker (SBi). Hardness, cohesiveness, and chewiness were significantly higher in gels at $\mathrm{pH}$ 7.0. The degree of proteolysis was higher in samples digested by IMGS-SBi (7-21\%) than SBg-SBi (3-5\%), regardless of the gel's pH. For SBg-SBi, the degree of proteolysis was not affected by $\mathrm{pH}$, but when operating the IMGS, higher hydrolysis values were obtained for gels at $\mathrm{pH} 7.0$ (15-21\%) than $\mathrm{pH} 4.0$ (7-13\%). Additionally, the percentage of free fatty acids (\%FFA) released was reduced by $47.9 \%$ in samples digested in the IMGS-SBi. For the methodology SBg-SBi, the \%FFA was not affected by the $\mathrm{pH}$, but in the IMGS, higher values were obtained for gels at $\mathrm{pH} 4.0(28-30 \%)$ than $\mathrm{pH} 7.0$ (15-19\%). Our findings demonstrate the importance of choosing representative methods to simulate food digestion in the human gastrointestinal tract and their subsequent impact on nutrient bioaccessibility.
\end{abstract}

Keywords: emulsion gel; in vitro digestion; gastric motility; gastric emptying; proteolysis; lipolysis

\section{Introduction}

Nowadays, the main nutritional problems of the world population, such as obesity or undernutrition, could be overcome by the adoption of different technological solutions [1]. These nutritional problems are directly linked to food intake, but it is not only the amount of food consumed that matters. Interactions between proteins, lipids and carbohydrates form the basis of the food matrix facing the digestive system. After digestion in the gastrointestinal tract (GIT), the release of the building blocks of macronutrients (e.g., amino acids, free fatty acids and/or glucose) is dependent on the food matrix structure and the complex processes occurring in the GIT [2]. This explains why, over the years, there has been increasing interest in understanding the behavior of food through the GIT [3].

Food digestion in humans or animals has traditionally been studied with in vivo approaches, but these approaches are expensive, invasive, and have ethical restrictions [3,4]. Consequently, various in vitro digestion systems that attempt to simulate the dynamic, physical and biochemical complexity of the GIT, and particularly systems that mimic the 
human stomach, have been developed: human gastric simulator (HGS) [5]; TNO gastric small intestinal model (TIM-1) (TNO: Nederlandse Organisatie voor Toegepast Natuurwetenschappelijk Onderzoek) [6-8]; dynamic gastric model (DGM) [9]; gastric digestion simulator (GDS) [10]; rope-driven in vitro human stomach model (RD-IV-HSM) [11]. However, some of these systems (HGS, TIM-1, DGM and GDS) have the disadvantage that they do not consider human stomach morphology and, during food digestion, simulated peristaltic movements are not realistically applied. This last point becomes a limitation when the results obtained from these digestion models are interpreted, since the enzyme activity is affected by the mixing of gastric contents and the exposed surface area available for the enzymatic attack, which is itself generated by the disintegration process caused by peristaltic movements. In the case of RD-IV-HSM, although its design considers the human stomach morphology, the gastric contractions generated are produced only at the antral zone. The in vivo contractions that occur throughout the body of the stomach cause the mixing of food with digestive fluids which are then transported by these same peristaltic movements to the small intestine [3,12].

Based on the previous literature, this study focuses on the use of an in vitro mechanical gastric system (IMGS) designed by our research group [13], which has comparative advantages to the systems that are currently available. These advantages are found in the simulation of the peristaltic movements that occur in an adult human stomach (peristaltic frequency and force magnitude), the J-shaped stomach, and reproduction of the gastric $\mathrm{pH}$ curve. In this work, the gastric emptying process was incorporated in the operation of the IMGS by applying a controlled pumping process, in order to obtain a greater precision of the digestion kinetics of solid food matrices, such as emulsion gels, as reported by in vivo studies [12]. In particular, emulsion gels are semisolid foods containing emulsified fats and oils $[14,15]$. In fact, it is known that the distal stomach regulates the rate of gastric emptying of solid meals by coordinated processes involving the antrum, pylorus and duodenum [16]. According to these characteristics, the IMGS can be a useful tool to establish a better understanding of the relationship between the physicochemical properties of foods, its digestion and the subsequent absorption of nutrients. The objective of this work was to study the impact of the methodology of in vitro gastric digestion, analyzed in terms of a system with realistic gastric peristalsis and emptying (IMGS) in comparison with a conventional system based on a stirred beaker operated at constant speed (SB), and gel structure, on the degree of intestinal proteolysis and lipolysis of emulsion gels stabilized by whey protein isolate (WPI). It is important to mention that in this work, measurements of gastric lipolysis of the emulsion gels were not considered because only 5 to $30 \%$ of ingested triglycerides are hydrolyzed in the human stomach [17-20]. Besides, gastric proteolysis was not considered, because a similar degree of gastric protein hydrolysis was found for different whey protein isolate emulsion gels using electrophoresis or titration [21,22], although the degree of gel fragmentation was different between "soft" and "hard" whey protein emulsion gels [21], depending on their structure (fine-stranded or particulate).

\section{Materials and Methods}

\subsection{Fabrication of Emulsion Gels}

Sunflower oil (Natura, Córdoba, Argentina) was purchased from a local supermarket. The major fatty acids of the sunflower oil used in this study were: $6.5 \% \mathrm{C} 16: 0 ; 3.9 \% \mathrm{C} 18: 0$; $26.3 \%$ C18:1 w9 cis; $57.3 \%$ C18:2 w6. Whey protein isolate (WPI) (BIPRO ${ }^{\text {TM }}$, Davisco Foods International Inc., Le Sueur, MN, USA) was used as emulsifier and gelling agent. Emulsion gels were prepared from a lipid and an aqueous phase, mixing 30\% (w/w) lipid phase (sunflower oil) with $70 \%(w / w)$ aqueous phase (protein dispersion). Protein dispersions were prepared at $9.0 \%(w / w)$ into phosphate-citrate buffer at $\mathrm{pH} 4.0$ and 7.0, which were subjected to continuous stirring for at least $1 \mathrm{~h}$ and at $25^{\circ} \mathrm{C}$. $\mathrm{pH} 4.0$ and 7.0 were chosen because it is widely known that whey proteins form different gel structures (coarse and fine-stranded gels, respectively) at these $\mathrm{pHs}$ [23-25]. The dispersions were kept overnight at $5{ }^{\circ} \mathrm{C}$ to ensure complete hydration of proteins. 
Pre-emulsions were elaborated at room temperature by dispersing the lipid phase into the aqueous phase using a rotor-stator homogenizer (Kinematica Polytron ${ }^{\circledR}$, PT 2500 E, Luzern, Switzerland) operated at $6000 \mathrm{rpm}$ for $5 \mathrm{~min}$. The $\mathrm{pH}$ of the pre-emulsions was adjusted to 7.0 if required. These pre-emulsions were processed in a high-pressure homogenizer (Gea Niro Soavi, model Panda Plus, Parma, Italy) operating at 500 or 1000 bar and at 3 homogenization steps. Afterwards, the emulsions were subjected to thermal treatment for the formation of the emulsion gels. Emulsions were heated in $50 \mathrm{~mL}$ plastic centrifuge tubes in order to set the gels. The tubes were immersed in a water bath (Memmert, model Basic WNB, Schwabach, Germany) at a constant temperature of $90^{\circ} \mathrm{C}$ for $30 \mathrm{~min}$. After the heat treatment, samples were cooled to ambient temperature $\left(25^{\circ} \mathrm{C}\right)$ and then were maintained for $24 \mathrm{~h}$ at $5^{\circ} \mathrm{C}$ for further study.

\subsection{Characterization of Particle Size of the Emulsions}

Mean particle size, particle size distribution and polydispersity index (Pdi) of the emulsions were evaluated using a dynamic laser light scattering instrument (Zetasizer Nano-ZS, Malvern Instruments, Worcestershire, UK). To avoid multiple scattering, emulsions were diluted with phosphate-citrate buffer at a ratio 1:5000 (v/v) before measurements. The results were calculated by the instrument software (Zetasizer software, version 6.10).

\subsection{Textural Characterization of the Emulsion Gels}

Cylindrical samples of gels $(2.5 \mathrm{~cm}$ diameter; $3 \mathrm{~cm}$ height $)$ were subjected to texture profile analysis (TPA) and compression test, using a texture analysis machine (Zwick/Roell, model Z0.5, Zwick GmbH \& CO, Ulm, Germany). For TPA, gel samples were compressed up to $20 \%$ of their original height using an aluminum cylinder probe $(5 \mathrm{~cm}$ diameter) operated at $0.1 \mathrm{~mm} / \mathrm{s}$. After assays, the parameters determined were: hardness (i.e., maximum force during the first cycle of compression), cohesiveness (i.e., related to the internal forces that maintain the structure of a food prior to rupture), and chewiness (i.e., work required to masticate the sample before swallowing) [26,27]. For the compression tests, gel samples were placed between two lubricated plates $(5 \mathrm{~cm}$ diameter) and compressed at $25^{\circ} \mathrm{C}$ at a constant deformation speed of $0.1 \mathrm{~mm} / \mathrm{s}$ until break [28]. Gel deformation was expressed as the Hencky's or true strain $\left(\varepsilon_{H}\right)$ (Equation (1)) described by:

$$
\varepsilon_{H}=-\ln \left(\frac{H}{H_{0}}\right)
$$

where $H$ and $H_{0}(\mathrm{~m})$ are the final and initial height after deformation, respectively. The overall stress acting on the sample during compression was expressed as the true normal stress, which is the normal force to the cylinder cross section divided by the initial area of the sample [28]:

$$
\sigma_{t}=\frac{F}{A_{0}}
$$

where $\sigma_{t}$ is the true normal stress $(\mathrm{Pa}), F$ is the normal force acting over the gel $(\mathrm{N})$ and $A_{0}$ is the cross-sectional area of the gel $\left(\mathrm{m}^{2}\right)$.

\subsection{In Vitro Digestion Assays of Emulsion Gels}

The standardized digestion method proposed by the COST Infogest network [29,30] was used as the basis to perform the in vitro digestion assays, with some modifications. Three phases of in vitro digestion were simulated: oral, gastric and intestinal phase. For gastric digestion, two methodologies were used: (i) IMGS, system composed by a human stomach model and a mechanical system with realistic peristalsis) [13], or (ii) SBg, gastric stirred beaker operated at $150 \mathrm{rpm}$. The impact of gastric emptying on the in vitro intestinal lipolysis and proteolysis of emulsion gels was studied. After gastric digestion using the IMGS or $\mathrm{SBg}$, the chyme obtained was subjected to intestinal digestion in a double-jacketed glass beaker under continuous stirring (called SBi). The gastric and intestinal digestion times were of 90 and $120 \mathrm{~min}$, respectively. 


\subsubsection{Preparation of Simulated Digestion Fluids}

The preparation of digestive juices was described in our previous works [13,31,32]. The enzymes used here were: $\alpha$-amylase (porcine pancreas, Sigma-Aldrich, St. Louis, MO, USA), pepsin (porcine gastric mucosa, Sigma-Aldrich, St. Louis, MO, USA), lipase (porcine pancreas, Sigma-Aldrich, St. Louis, MO, USA), pancreatin (porcine pancreas, Sigma-Aldrich, St. Louis, MO, USA), trypsin (porcine pancreas, Fermelo Biotec, Santiago, Chile), and chymotrypsin (bovine pancreas, Fermelo Biotec, Santiago, Chile). Bile extract (porcine, Sigma Aldrich, St. Louis, MO, USA), soy lecithin (Blumos, Santiago, Chile), $1 \mathrm{~N}$ $\mathrm{HCl}$ (Fisher Chemical, Pittsburg, PA, USA) and $1 \mathrm{~N} \mathrm{NaOH}$ (Heyn, Santiago, Chile) were also used. Purified water was used for the preparation of all solutions. To simulate the gastrointestinal fluids, simulated salivary fluid (SSF), simulated gastric fluid (SGF) and simulated intestinal fluid (SIF) were prepared, which were adjusted to $\mathrm{pH}$ values of 7.0, 3.0 and 7.0, respectively. Simulated fluids were made up of the corresponding electrolyte stock solutions, enzymes, $\mathrm{CaCl}_{2}$ and water, according to the standardized digestion method. The concentration of the stock solutions was based on the method proposed by the COST Infogest network $[29,30]$ (Table 1). For all assays, freshly prepared simulated digestion fluids were used.

Table 1. Concentration of stock solutions of simulated digestion fluids.

\begin{tabular}{ccccc}
\hline Constituent & $\begin{array}{c}\text { Stock Concentration } \\
\text { (mol/L) }\end{array}$ & $\begin{array}{c}\text { Concentration in } \\
\text { Simulated Salivary } \\
\text { Fluid, SSF (mmol/L) }\end{array}$ & $\begin{array}{c}\text { Concentration in } \\
\text { Simulated Gastric Fluid, } \\
\text { SGF (mmol/L) }\end{array}$ & $\begin{array}{c}\text { Concentration in } \\
\text { Simulated Intestinal } \\
\text { Fluid, SIF (mmol/L) }\end{array}$ \\
\hline $\mathrm{KCl}$ & 0.5 & 15.1 & 6.9 & 6.8 \\
$\mathrm{KH}_{2} \mathrm{PO}_{4}$ & 0.5 & 3.7 & 0.9 & 0.8 \\
$\mathrm{NaHCO}_{3}$ & 1.0 & 13.6 & 25.0 & 85.0 \\
$\mathrm{NaCl}$ & 2.0 & - & 47.2 & 38.4 \\
$\mathrm{MgCl}_{2}\left(\mathrm{H}_{2} \mathrm{O}\right)_{6}$ & 0.15 & 0.15 & 0.12 & 0.33 \\
$\left(\mathrm{NH}_{4}\right)_{2} \mathrm{CO}_{3}$ & 0.5 & 0.06 & 0.5 & - \\
$\mathrm{HCl}$ & 6.0 & 1.1 & 15.6 & 8.4 \\
\hline
\end{tabular}

Data based on $[29,30]$.

\subsubsection{In Vitro Oral Digestion}

In total, $150 \mathrm{~g}$ of emulsion gel ( $150 \mathrm{~mL}$; $\mathrm{pH} 4.0$ or 7.0$)$ was mixed with $150 \mathrm{~mL}$ of SSF (divided into 5 charges, $30 \mathrm{~g}$ gel $+30 \mathrm{~mL}$ SSF each one), following the mix 1:1 with SSF-containing amylase $(75 \mathrm{U} / \mathrm{mL})[29,30]$. Each charge of this mixture (emulsion gel and SSF) was deposited in dialysis bags. After that, the bags were sealed tightly with adhesive tape, and then were chewed by a human volunteer. As oral residence time depends on the nature and textural characteristics of the material [12], the crushing times were 40 and $60 \mathrm{~s}$ for the samples at $\mathrm{pH} 4.0$ and $\mathrm{pH} 7.0$, respectively.

\subsubsection{In Vitro Gastric Digestion}

As previously mentioned, these assays were carried out in the IMGS or SBg. In both cases, $300 \mathrm{~mL}$ of bolus from the in vitro oral digestion was mixed with $300 \mathrm{~mL} \mathrm{SGF}$, following the mix 1:1 with SGF-containing pepsin $(2000 \mathrm{U} / \mathrm{mL})[29,30]$. For each methodology (IMGS or SBg) and type of sample (emulsion gel at $\mathrm{pH} 4.0$ and 7.0), a gastric $\mathrm{pH}$ curve was performed (Figure 1), since it is known that when a food enters the human stomach, a buffering effect is induced by the food, after which acid secretion produces an exponential decrease in $\mathrm{pH}$. This $\mathrm{pH}$ change has been described for in vivo $[33,34]$ and in vitro $[5,35]$ studies, which were used as a reference to build up a programmed $\mathrm{pH}$ curve. The $\mathrm{pH}$ curve developed for the IMGS considered the gastric-emptying process. 


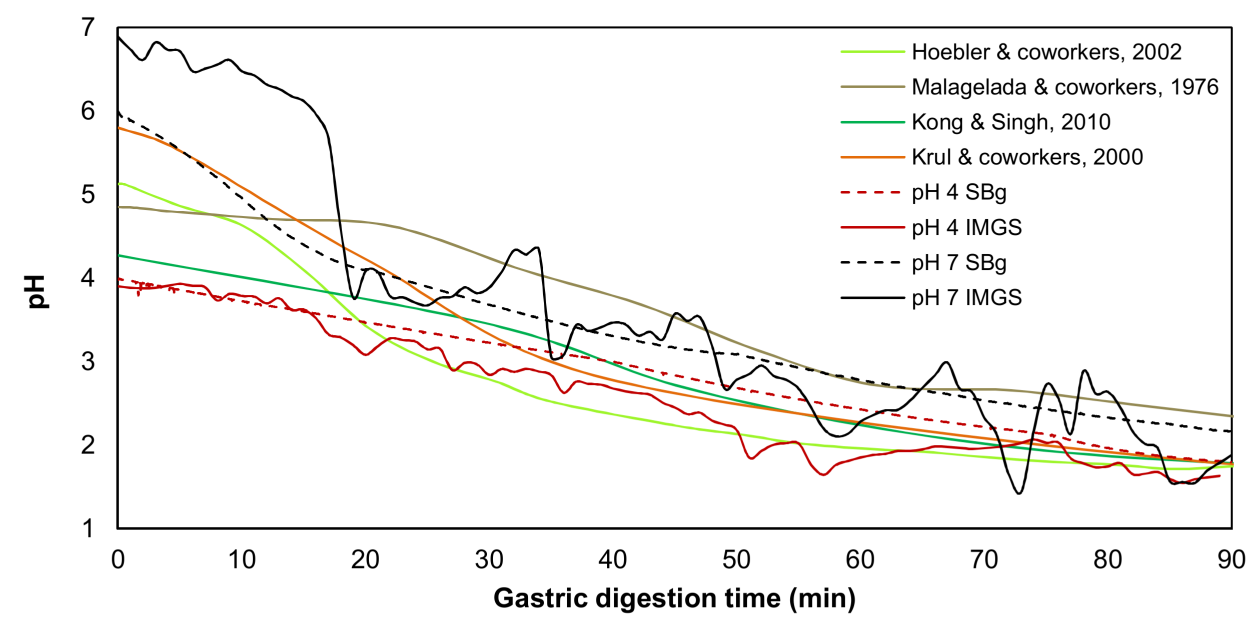

Figure 1. Variation of gastric $\mathrm{pH}$ during the in vitro digestion in the IMGS and in a stirred beaker $(\mathrm{SBg})$ of the emulsion gels stabilized by whey protein isolate (WPI), in comparison with the literature data.

The gastric digestion procedures applied were:

SBg. The bolus was mixed with SGF $\left(37^{\circ} \mathrm{C}\right.$; $\left.\mathrm{pH} 3.0\right)$ and the $\mathrm{pH}$ of this mixture was immediately controlled by a pH-Stat automatic titration unit (Metrohm, 902 Titrando, Herisau, Switzerland). In its software (Tiamo 2.4), the parameters were adjusted in order to obtain the expected gastric $\mathrm{pH}$ curve by adding defined volumes of $0.5 \mathrm{~N} \mathrm{HCl}$ solution at different time intervals, until completing the test period $(90 \mathrm{~min})$.

IMGS. The bolus was deposited in the simulated stomach of the IMGS, and the SGF was added at a rate of $3.33 \mathrm{~mL} / \mathrm{min}$ by pumping (Surefusion ${ }^{\mathrm{TM}}$, Nipro, Osaka, Japan). The rate of flow of gastric juice was representative of that found in in vivo studies $[9,34,36]$. Simultaneously, the IMGS operation started, exerting the peristalsis in the stomach at a frequency of 3 cycles/min, physiological value of the human stomach $[37,38]$. For simulation of the gastric $\mathrm{pH}$ curve, the same method used for SBg was applied (Figure 1). After the first $15 \mathrm{~min}$, the gastric emptying valve placed at the pyloric section of the simulated stomach was opened. The gastric emptying was performed intermittently every $10 \mathrm{~min}$ using a peristaltic pump (Fisherbrand ${ }^{\mathrm{TM}}$ 13-876-2, Fisher Scientific, Suwanee, GA, USA), until completing the whole digestion period $(120 \mathrm{~min})$, following the phenomenology reported by in vivo studies [12]. The gastric chyme was transferred at a rate of $10 \mathrm{~mL} / \mathrm{min}$ to the intestinal phase $[36,39]$, with previous adjustment of $\mathrm{pH}$ to 7.0 . At the pyloric zone, a membrane (pore size: $2 \mathrm{~mm}$ ) was incorporated to control the particle size of the chyme passing to intestinal digestion [5]. During IMGS digestion, the overall mechanical force exerted on the emulsion gels samples at $\mathrm{pH} 4.0$ and 7.0 was measured as reported previously [13], obtaining values between the ranges of $0.2-1.2 \mathrm{~N}$ and $0.2-1.5 \mathrm{~N}$, respectively. These results are in line with those found in an adult human stomach $[37,40]$.

\subsubsection{In Vitro Intestinal Digestion}

The intestinal phase was carried out in a double-jacketed beaker at $37^{\circ} \mathrm{C}$ subjected to continuous agitation at $150 \mathrm{rpm}$ (SBi). After digesting in the SBg, the gastric chyme obtained (650 mL; pH 2.0 as shown in Figure 1) was adjusted to pH 7.0 with $1 \mathrm{~N} \mathrm{NaOH}$ solution. Immediately after that, the chyme was transferred to the SBi and then mixed with $650 \mathrm{~mL}$ of SIF $\left(37^{\circ} \mathrm{C}\right.$; $\mathrm{pH} 7.0$ ), following the mix 1:1 with SIF-containing enzymes [29,30]. For the studies of intestinal proteolysis, the SIF was only composed by trypsin $(100 \mathrm{U} / \mathrm{mL})$, pancreatin based on trypsin activity at $100 \mathrm{U} / \mathrm{mL}$, and chymotrypsin $(25 \mathrm{U} / \mathrm{mL})$; however, for the intestinal lipolysis assays, the SIF also contained lipase $(2000 \mathrm{U} / \mathrm{mL})[29,30]$.

When digesting in the IMGS, the gastric chyme at $\mathrm{pH} \sim 2.0$ (see Figure 1) was emptied at $10 \mathrm{~mL} / \mathrm{min}$ into the SBi [36,39], with previous adjustment of $\mathrm{pH}$ to 7.0 with $1 \mathrm{~N} \mathrm{NaOH}$ solution as mentioned previously. The neutralized chyme was then mixed with SIF $\left(37^{\circ} \mathrm{C}\right.$; 
pH 7.0) pumped (Surefusion ${ }^{\mathrm{TM}}$, Nipro, Japan) at a rate of $5.4 \mathrm{~mL} / \mathrm{min}$ into the SBi, until it reached the total volume $(650 \mathrm{~mL})$. The flow rate of the simulated intestinal fluid is in accordance with previous studies reporting values of intestinal secretion in the small intestine ranging from 0.3 to $20.8 \mathrm{~mL} / \mathrm{min}$, measured from human volunteers [41-44].

During intestinal digestion, and after neutralizing the gastric chyme, sample $\mathrm{pH}$ was monitored by using an automatic titration unit (Metrohm, 902 Titrando, Herisau, Switzerland) and maintained at a value of 7.0 by adding $0.7 \mathrm{~N} \mathrm{NaOH}$ solution during the 120 min of digestion. The volume of $\mathrm{NaOH}$ solution added to the digested mixture was recorded and used to calculate the intestinal hydrolysis of proteins and lipids.

\subsection{Quantification of the Intestinal Proteolysis and Lipolysis of Emulsion Gels}

\subsubsection{Intestinal Proteolysis}

After hydrolyzing a peptide bond, one carboxylic group and one $\alpha$-amino group are produced. During the in vitro digestion at $\mathrm{pH} 7.0$, carboxylic groups release their proton, which can be titrated by $\mathrm{NaOH}$ solution using a $\mathrm{pH}$-stat automatic titration [45]. The volume of $\mathrm{NaOH}$ solution added can be converted into the degree of intestinal protein hydrolysis (DH), as follows [45,46]:

$$
\% \mathrm{DH}=\left[\frac{\mathrm{V}_{\mathrm{NaOH} \text { proteolysis }}(\mathrm{t}) \times \mathrm{N}_{\mathrm{NaOH}}}{\alpha\left(\mathrm{RNH}_{2}\right) \times \mathrm{m}_{\text {protein }} \times \mathrm{h}_{\mathrm{tot}}}\right] \times 100 \%
$$

where $\mathrm{V}_{\mathrm{NaOH} \text { proteolysis }}(\mathrm{t})$ is the volume of $\mathrm{NaOH}$ consumed during a t protein digestion time (L), $\mathrm{N}_{\mathrm{NaOH}}$ is the $\mathrm{NaOH}$ normality (eq/L), $\mathrm{m}_{\text {protein }}$ is the initial protein mass in the sample $(\mathrm{g}), \mathrm{h}_{\text {tot }}$ is the number of peptide bonds in the protein substrate $(8.8 \mathrm{meqv} / \mathrm{g}$ for whey proteins [47]), and $\alpha\left(\mathrm{RNH}_{2}\right)$ is the mean degree of dissociation of $\alpha$ amino groups, which can be calculated as follows:

$$
\alpha\left(\mathrm{RNH}_{2}\right)=\frac{10^{(\mathrm{pH}-\mathrm{pK})}}{1+10^{(\mathrm{pH}-\mathrm{pK})}}
$$

As $\mathrm{pK}$ is dependent on the working temperature $\left(37^{\circ} \mathrm{C}\right.$, physiological temperature) and $\mathrm{pH}(7.0)$, its value for this study was 7.4, and therefore $\alpha\left(\mathrm{RNH}_{2}\right)$ corresponds to $0.285[46,48]$.

\subsubsection{Intestinal Lipolysis}

Each triacylglycerol (TAG) molecule generates two free fatty acids (FFA) when fully digested. The FFA released from a sample can be calculated from the total amount of TAG present in the original sample, according to [13]:

$$
\% \mathrm{FFA}=\frac{\left[\mathrm{V}_{\mathrm{NaOH} \text { lipolysis }}(\mathrm{t})-\mathrm{V}_{\mathrm{NaOH} \text { proteolysis }}(\mathrm{t})\right] \times \mathrm{M}_{\mathrm{NaOH}} \times \mathrm{MM}_{\text {lipid }}}{\mathrm{m}_{\text {lipid }} \times 2} \times 100 \%
$$

where $\mathrm{V}_{\mathrm{NaOH} \text { lipolysis }}(\mathrm{t})$ is the volume of $\mathrm{NaOH}$ solution required to neutralize the FFA produced at lipid digestion time $\mathrm{t}(\mathrm{L}), \mathrm{M}_{\mathrm{NaOH}}$ is the molarity of the $\mathrm{NaOH}$ solution (mol/L), $\mathrm{MM}_{\text {lipid }}$ is the molecular mass of the TAG oil $(\mathrm{g} / \mathrm{mol})$, and $\mathrm{m}_{\text {lipid }}$ is the total mass of TAG oil initially present in the sample (g). When lipolysis was analyzed, the final \%FFA was obtained by subtracting the respective volume of $\mathrm{NaOH}$ solution used in the proteolysis calculation. The times used to estimate the FFA released were the same as those from the degree of intestinal protein hydrolysis. Control runs without enzymes were also performed and subtracted from the reported values.

\subsection{Statistical Analysis of Data}

All experiments were carried out in triplicate using freshly prepared samples. Results are presented as mean values with standard deviations. Analysis of variance was carried out when required using Statgraphic Centurion XVI (version 16.1, Statistical Graphics 
Corporation, Rockville, MD, USA), including multiple range tests $(p<0.05)$ for separation of the least square means.

\section{Results and Discussion}

\subsection{Characterization of Emulsions and Emulsion Gels}

The oil droplet sizes and the size distributions for the four oil-in-water $(\mathrm{O} / \mathrm{W})$ emulsions stabilized by WPI are presented in Table 2 and Figure 2. Both particle size and Pdi of the emulsions were not significantly affected $(p>0.05)$ by the homogenization pressure, reaching values of $302-328 \mathrm{~nm}$ and $\sim 0.19$ for emulsions at $\mathrm{pH} 4.0$, and $\sim 275 \mathrm{~nm}$ and $0.10-0.17$ for emulsions at $\mathrm{pH} 7.0$, respectively. The decrease in oil droplet diameter by increasing the homogenization pressure (500 bar vs. 1000 bar) was only observed in $\mathrm{pH} 4.0$ emulsions (328 nm vs. $302 \mathrm{~nm}$, respectively), whereas in emulsions at $\mathrm{pH} 7.0$, the droplet diameter ranged from $260 \mathrm{~nm}$ to $271 \mathrm{~nm}$, respectively. The latter can be attributed to the limited amount of surfactant present to stabilize the droplets formed [49]. It is probable that disruptive forces would be able to generate smaller drops at 1000 bar, but even when there is a sufficient amount of surfactant for emulsion formation, it did not adsorb quickly enough during homogenization. Under turbulent flow conditions, as expected in high-pressure homogenization, newly formed droplets collide, which may lead to rapid recoalescence depending on the extent to which droplets are readily covered by emulsifier molecules [50]. Very short timescales are involved in droplet coverage, and whey proteins were presumably unable to completely stabilize small droplets at 1000 bar.

Table 2. Mean oil droplet diameter and polydispersity index (Pdi) of O/W emulsions stabilized by WPI at different $\mathrm{pH}$ and elaborated at different homogenization pressures.

\begin{tabular}{cccc}
\hline pH & $\begin{array}{c}\text { Homogenization } \\
\text { Pressure (bar) }\end{array}$ & $\begin{array}{c}\text { Mean Oil Droplet } \\
\text { Diameter (nm) }\end{array}$ & Pdi \\
\hline 4 & 500 & $327.8 \pm 22.9^{\mathrm{aA}}$ & $0.20 \pm 0.04^{\mathrm{aA}}$ \\
& 1000 & $301.8 \pm 7.1^{\mathrm{aA}}$ & $0.18 \pm 0.02^{\mathrm{aA}}$ \\
7 & 500 & $260.4 \pm 21.7^{\mathrm{bA}}$ & $0.10 \pm 0.03^{\mathrm{bA}}$ \\
& 1000 & $270.8 \pm 0.7^{\mathrm{bA}}$ & $0.17 \pm 0.01^{\mathrm{bA}}$ \\
\hline
\end{tabular}

Different lowercase letters indicate significant differences $(p<0.05)$ between $\mathrm{pH}$ of the $\mathrm{O} / \mathrm{W}$ emulsions, and different capital letters indicate significant differences $(p<0.05)$ between homogenization pressures.

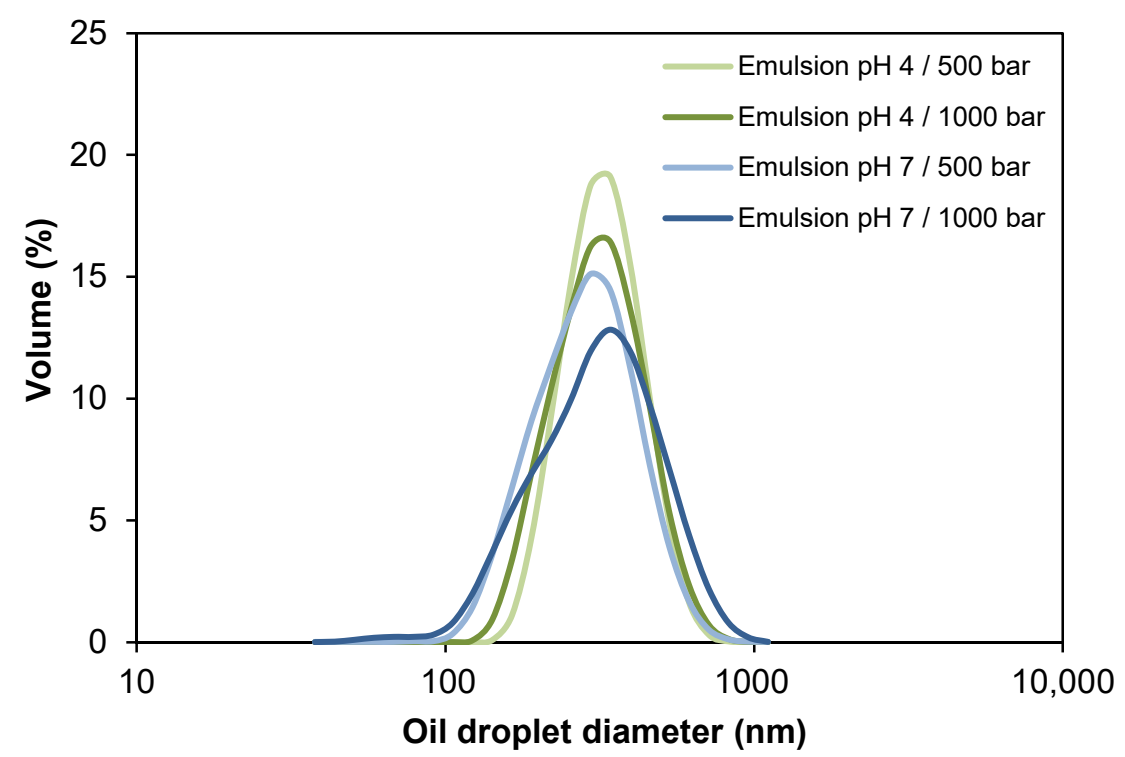

Figure 2. Influence of $\mathrm{pH}$ and homogenization pressure on the oil droplet size distribution of $\mathrm{O} / \mathrm{W}$ emulsions. 
Unlike the pressure factor, the $\mathrm{pH}$ of the emulsions affected the particle size and Pdi, both being significantly lower $(p<0.05)$ at $\mathrm{pH}$ 7.0. This can be explained by the lower stability of whey proteins in dispersion at $\mathrm{pH} 4.0$, since when they are in an environment close to its isoelectric point ( $\mathrm{pH}$ 5.2), they tend to aggregate, giving way to destabilization phenomena (e.g., coalescence or flocculation). Thus, oil droplets would form larger droplets or aggregates in the dispersion [51,52]. All the samples presented Pdi $<0.20$ (Table 2), which indicates monodisperse size distributions (Figure 2) [53].

With respect to the textural characterization of the emulsion gels, results from the TPA test (Table 3 ) indicate that the hardness and cohesiveness were affected only by $\mathrm{pH}$. In the case of hardness, the values were $\sim 10 \mathrm{~N}$ for gels at $\mathrm{pH} 4.0$, and $\sim 12 \mathrm{~N}$ for gels at $\mathrm{pH}$ 7.0. In turn, gels at $\mathrm{pH} 4.0$ and 7.0 presented values of cohesiveness of $\sim 0.45$ and 0.87 , respectively. Both properties were significantly higher $(p<0.05)$ for $\mathrm{pH} 7.0$ emulsion gels. It is known that fine-stranded WPI gels are formed at $\mathrm{pH}$ 7.0, which gives them a more rigid conformation generated by disulfide bonds (covalent interactions) [54-56]. This would explain the harder and more cohesive structure of these gels. In addition, it has been indicated that an increase in rigidity of emulsion gels prepared from WPI-stabilized emulsions can be obtained by lowering the emulsion oil droplet size [14]. At pH 4.0, whey proteins tend to aggregate and a coarse (particulate) gel structure with fewer covalent binding points is generated [57], decreasing the hardness and cohesiveness of these gels.

Table 3. Textural properties of emulsion gels stabilized by WPI.

\begin{tabular}{ccccccc}
\hline \multirow{2}{*}{$\mathbf{p H}$} & $\begin{array}{c}\text { Pressure } \\
\text { (bar) }\end{array}$ & $\begin{array}{c}\text { Hardness } \\
(\mathbf{N})\end{array}$ & $\begin{array}{c}\text { Cohesiveness } \\
\text { (Dimensionless) }\end{array}$ & $\begin{array}{c}\text { Chewiness } \\
\mathbf{( N )}\end{array}$ & $\begin{array}{c}\text { Stress at Break } \\
\text { (kPa) }\end{array}$ & $\begin{array}{c}\text { Strain at Break } \\
(\text { Dimensionless) }\end{array}$ \\
\cline { 3 - 7 } & & $10.81 \pm 0.55^{\mathrm{aA}}$ & $0.44 \pm 0.01^{\mathrm{aA}}$ & $4.57 \pm 0.10^{\mathrm{aA}}$ & $21.70 \pm 0.83^{\mathrm{aA}}$ & $0.21 \pm 0.04^{\mathrm{aA}}$ \\
& 500 & $8.97 \pm 0.34^{\mathrm{aA}}$ & $0.46 \pm 0.02^{\mathrm{aA}}$ & $3.77 \pm 0.53^{\mathrm{aB}}$ & $23.43 \pm 1.49^{\mathrm{aB}}$ & $0.24 \pm 0.01^{\mathrm{aA}}$ \\
& 1000 & $11.31 \pm 0.12^{\mathrm{bA}}$ & $0.89 \pm 0.02^{\mathrm{bA}}$ & $8.52 \pm 0.38^{\mathrm{bA}}$ & $76.21 \pm 2.34^{\mathrm{bA}}$ & $0.75 \pm 0.12^{\mathrm{bA}}$ \\
& 500 & $13.27 \pm 0.28^{\mathrm{bA}}$ & $0.86 \pm 0.01^{\mathrm{bA}}$ & $7.40 \pm 0.40^{\mathrm{bB}}$ & $94.96 \pm 2.51^{\mathrm{bB}}$ & $0.76 \pm 0.21^{\mathrm{bA}}$ \\
\hline
\end{tabular}

Different lowercase letters indicate significant differences $(p<0.05)$ between $\mathrm{pH}$ of the emulsion gels, and different capital letters indicate significant differences $(p<0.05)$ between homogenization pressures.

Table 3 shows a congruence between the TPA results and the stress at break values. The $\mathrm{pH}$ of the emulsion gels significantly affected $(p<0.05)$ the stress at break, where lower compression stresses (21.7-23.4 kPa) were needed to break the $\mathrm{pH} 4.0$ samples. For $\mathrm{pH} 7.0$ emulsion gels, higher stresses were required (76.2-95.0 kPa) to deform and break up the sample, which can be associated with a longer period of chewing during the in vitro oral digestion ( $40 \mathrm{~s}$ for gels at $\mathrm{pH} 4.0 \mathrm{vs.} 60 \mathrm{~s}$ for gels at $\mathrm{pH} 7.0$, as described previously). Accordingly, the chewiness of the emulsion gels was significantly different $(p<0.05)$ when changing the $\mathrm{pH}$ from 4.0 to 7.0 and by varying the homogenization pressure. Emulsion gels at $\mathrm{pH} 7.0 \mathrm{had}$ a higher hardness and were more elastic; hence, a greater force $(8.5 \mathrm{~N} / 500 \mathrm{bar}$ vs. $7.4 \mathrm{~N} / 1000$ bar) was needed to chew the food and turn it into a bolus, so that there is a proportional relationship between both parameters [58]. The deformation of the samples was significantly affected $(p<0.05)$ only by $\mathrm{pH}$, resulting in a greater deformation before rupture for samples at $\mathrm{pH} 7.0$ due to its structural conformation induced by disulfide bonds, generating stronger and more elastic gels [56].

\subsection{In Vitro Digestibility of Emulsion Gels}

The impact of the type of gastric digestion (IMGS vs. SBg) of emulsion gels elaborated at different $\mathrm{pH}$ and homogenization pressures on the in vitro intestinal proteolysis (\%DH) and lipolysis (\%FFA) was evaluated. $\mathrm{pH}$ curves were constructed for both methodologies of gastric digestion to simulate more realistically food digestion in the stomach. 


\subsubsection{Gastric $\mathrm{pH}$ Curves}

The gastric $\mathrm{pH}$ curves obtained during digestion of emulsion gels in the IMGS and SBg systems are shown in Figure 1. When beginning the digestion, the gastric $\mathrm{pH}$ was $\sim 3.8$ and 6.5 for gels fabricated at $\mathrm{pH} 4.0$ and 7.0, respectively. Later, a decrease in $\mathrm{pH}$ of the gastric content digested using the IMGS and SBg methodologies was observed. Both gastric digestion systems showed $\mathrm{pH}$ changes similar to those reported for in vitro [33,34] and in vivo studies [5,35], with $\mathrm{pH}$ values decreasing to 2.0 after $90 \mathrm{~min}$ of digestion. From Figure 1, it is evident that the mixing process in the $\mathrm{SBg}$ is faster, because smoother $\mathrm{pH}$ curves were obtained in comparison with the noisy $\mathrm{pH}$ curves observed when digesting in the IMGS. In the SBg system, continuous agitation was used (similar to a perfectly stirred reactor), which promoted a more homogeneous mixture of the gastric content, independent of gel size resulting from the oral phase by crushing or chewing. In fact, $\mathrm{pH} 4.0$ gels subjected to oral digestion resulted in a paste-like consistency bolus with respect to the particulate state found for gels at pH 7.0 (Figure 3). Regardless of the physical state of the gels after oral digestion, there are no drastic variations in $\mathrm{pH}$ during digestion given the effect of the gastric mixing or homogenization. For the IMGS, it should be noted that the $\mathrm{pH}$ curves were performed applying realistic peristalsis and gastric emptying. Thus, the mixture of the gastric content (digested gel, $\mathrm{SFG}$ and $\mathrm{HCl}$ solution) is less homogeneous than in the SBg, which leads to oscillations in the gastric $\mathrm{pH}$ curves. These oscillations were less marked for $\mathrm{pH} 4.0$ gels, since the respective bolus formed after oral digestion presented a paste-like consistency (Figure 3), which facilitates the passage of chyme into the intestinal phase (SBi) by action of the gastric emptying process.

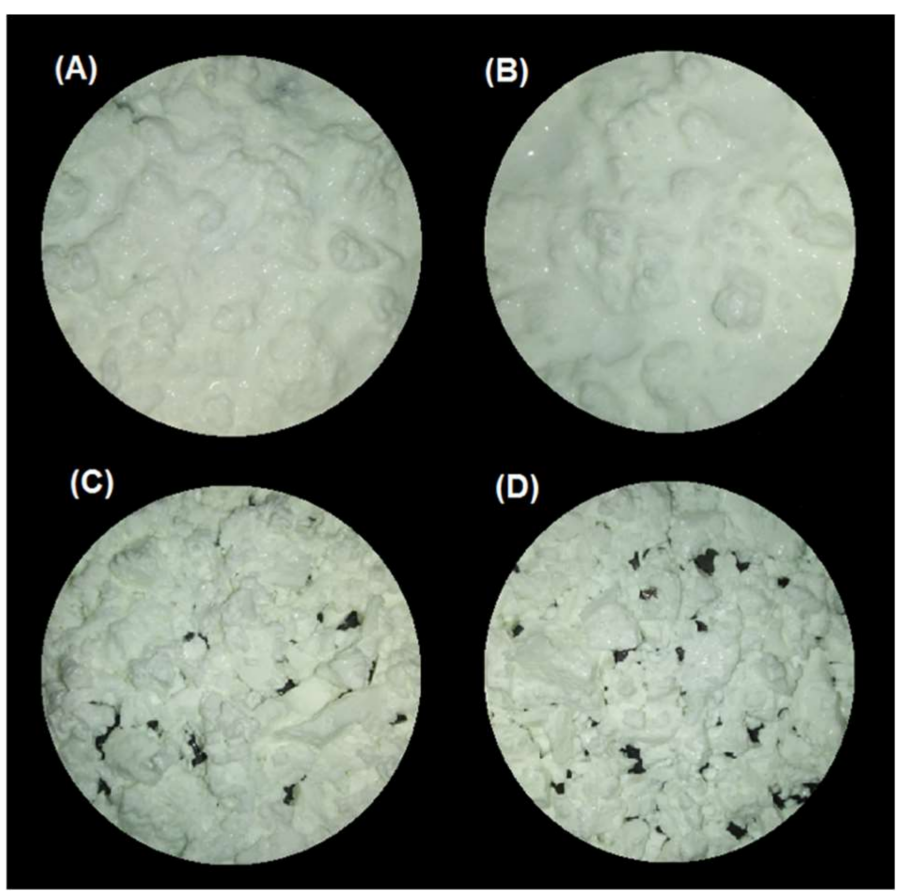

Figure 3. Images of the bolus obtained after oral digestion of the different emulsion gels stabilized by WPI. (A) pH 4/500 bar, (B) pH 4/1000 bar, (C) pH 7/500 bar, and (D) pH 7/1000 bar.

3.2.2. Impact of the Type of In Vitro Gastric Digestion of Emulsion Gels on the Degree of Intestinal Proteolysis

The kinetics of proteolysis of the emulsion gels during their in vitro intestinal digestion (SBi system) are shown in Figure 4. The nomenclature SBg-SBi refers to the gastric and intestinal digestion assays performed in a stirred beaker, whereas IMGS-SBi refers to the assays of gastric digestion in the IMGS and subsequent intestinal digestion in a stirred beaker. As is clear from Figure 4, the kinetics of intestinal proteolysis of the emulsion gels are markedly different among methodologies. While in the SBg-SBi systems these 
kinetics are very similar for all samples and do not present a lag phase, the kinetics obtained by the methodology IMGS-SBi showed a difference in shape according to the $\mathrm{pH}$ of the studied sample, and showed the existence of a lag phase whose extent was dependent on pH sample.
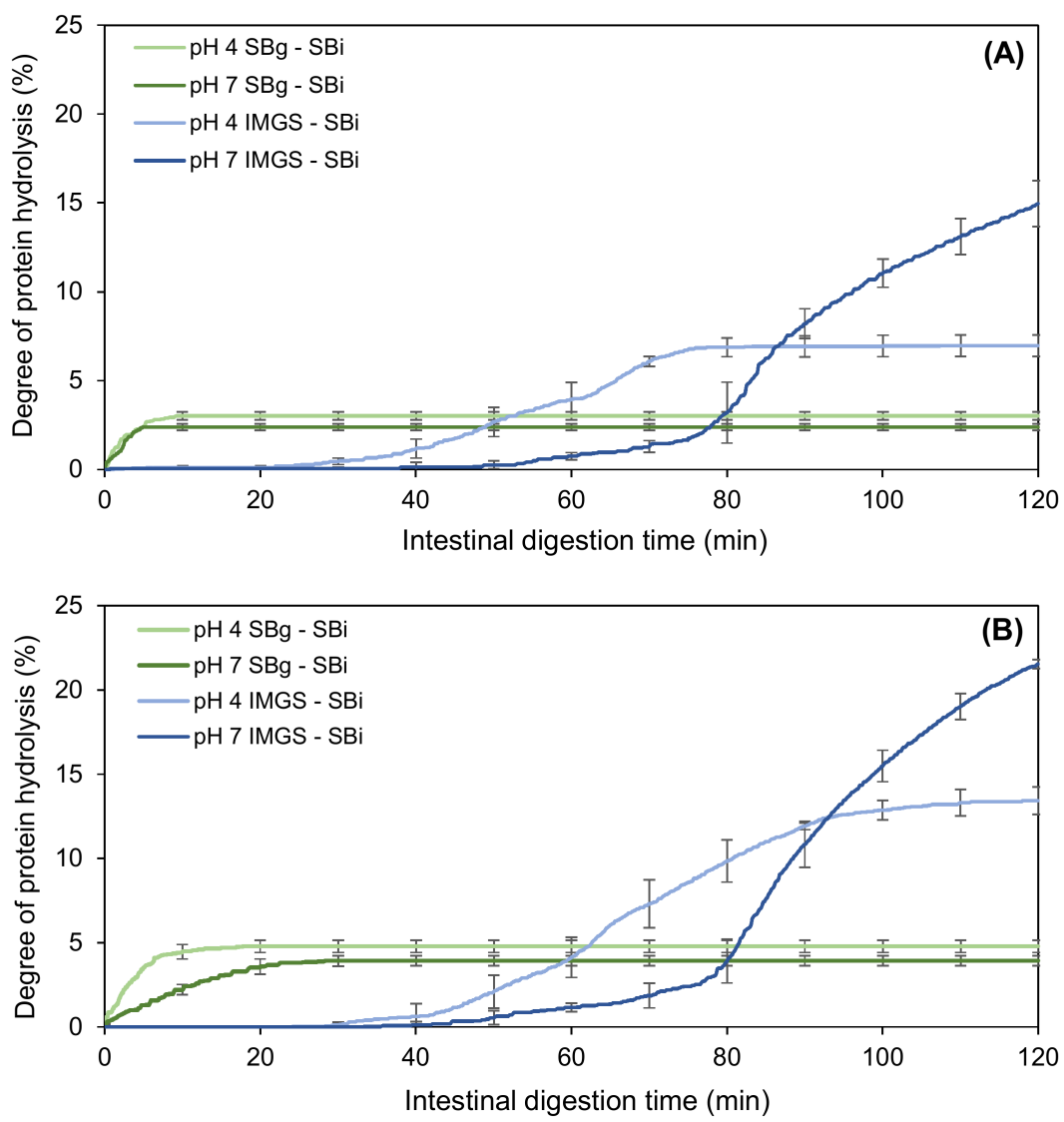

Figure 4. Kinetics of in vitro intestinal proteolysis using the systems IMGS-SBi and SBg-SBi for emulsion gels stabilized by WPI and fabricated at 500 bar (A) and 1000 bar (B). IMGS: In vitro mechanical gastric system; SBg: in vitro gastric digestion in a stirred beaker; SBi: in vitro intestinal digestion in a stirred beaker.

After gastric digestion, the total chyme obtained is transferred to the intestinal phase, which results in the absence of a lag phase for the samples subjected to digestion SBg-SBi. Accordingly, all the substrate (undigested protein or proteolytic fragments) is available to be hydrolyzed by trypsin and chymotrypsin, and consequently immediate intestinal proteolysis can occur. On the contrary, the lag phase observed for samples assayed with the methodology IMGS-SBi, where the substrate is not hydrolyzed immediately, can be explained by the application of the gastric-emptying process. When the gastric emptying begins, the chyme transported to the intestinal phase is a liquid that contains little substrate available because in the first minutes of gastric digestion, the disintegration of the gels is still reduced. Whether it is hydrolyzed by pepsin or not, the amount of protein that passes to the intestinal phase is low, resulting in the presence of this lag phase. In fact, it has been demonstrated that proteins behave differently at different digestive phases, such as gastric emptying rate [59]. Alternatively, significantly higher percentages of proteolysis $(p<0.05)$ were obtained using IMGS-SBi, with values ranging from $\sim 7.0 \%$ to $21.5 \%$ with respect to SBg-SBi (Table 4). This may indicate an underestimation of the hydrolysis degrees reported when studying intestinal proteolysis using digestion systems that operate as batch perfectly agitated vessels. From Figure 4, it can be seen that all the samples tested using SBg-SBi quickly increase their digestion rate, but this rate decreases in a short time until reaching a plateau period in which the generated proteolytic products remain constant. Notably, 
low final extent of proteolysis was found for all samples, with values ranging between $2.4 \%$ and $4.8 \%$ (Table 4 ). The rapid decrease in the rate of protein digestion can be caused by the possible inhibition of enzymes due to the effect of the substrate or hydrolytic products accumulated in the system during digestion time $[60,61]$. Thus, in this study it is possible to infer that the low proteolysis values reached for the SBg-SBi system could be due to trypsin and/or chymotrypsin inhibition during the intestinal digestion of the samples, where the enzymes lose their activity and therefore no reaction products continue to be generated after $\sim 10 \mathrm{~min}$ of substrate/enzyme contact. The above is possible because, as already mentioned for this system, after gastric digestion all the chyme is subjected to intestinal digestion. For this reason, the enzyme will be in contact with all the available substrates from the beginning, which induces its possible inhibition.

Table 4. Final extent of intestinal lipolysis and proteolysis using different methodologies of in vitro digestion for emulsion gels stabilized by WPI.

\begin{tabular}{|c|c|c|c|c|}
\hline \multicolumn{2}{|c|}{ Fabrication Conditions of the Emulsion Gels } & \multirow{2}{*}{$\begin{array}{l}\text { Methodology of } \\
\text { In Vitro Digestion } \\
\text { (Gastric-Intestinal) }\end{array}$} & \multicolumn{2}{|c|}{ Final Extent of Intestinal Digestion } \\
\hline $\mathrm{pH}$ & Pressure (bar) & & $\begin{array}{c}\text { Lipolysis } \\
\text { (Free Fatty Acids } \\
\text { Released \%) }\end{array}$ & $\begin{array}{c}\text { Proteolysis } \\
\text { (Protein Hydrolysis } \\
\% \text { ) }\end{array}$ \\
\hline \multirow{2}{*}{4.0} & 500 & \multirow{4}{*}{$\mathrm{SB}_{\mathrm{g}}-\mathrm{SB}_{\mathrm{i}}$} & $43.92 \pm 0.48^{\mathrm{a}, \mathrm{A}}$ & $3.01 \pm 0.22^{\mathrm{b}, \mathrm{A}}$ \\
\hline & 1000 & & $46.74 \pm 1.744^{\mathrm{a}, \mathrm{A}}$ & $4.78 \pm 0.36^{\mathrm{b}, \mathrm{A}}$ \\
\hline \multirow{2}{*}{7.0} & 500 & & $42.59 \pm 2.43^{\mathrm{a}, \mathrm{A}}$ & $2.39 \pm 0.19^{\mathrm{a}, \mathrm{B}}$ \\
\hline & 1000 & & $44.51 \pm 3.35^{\mathrm{a}, \mathrm{A}}$ & $3.93 \pm 0.30^{\mathrm{a}, \mathrm{B}}$ \\
\hline \multirow{2}{*}{4.0} & 500 & \multirow{4}{*}{ IMGS-SB $_{\mathrm{i}}$} & $28.24 \pm 5.53^{\mathrm{b}, \mathrm{A}}$ & $6.97 \pm 0.60 \mathrm{a}, \mathrm{A}$ \\
\hline & 1000 & & $29.85 \pm 4.87^{\mathrm{b}, \mathrm{A}}$ & $13.43 \pm 0.83^{\mathrm{a}, \mathrm{B}}$ \\
\hline \multirow{2}{*}{7.0} & 500 & & $19.41 \pm 3.76^{\mathrm{a}, \mathrm{A}}$ & $14.95 \pm 1.29 \mathrm{~b}, \mathrm{~A}$ \\
\hline & 1000 & & $15.16 \pm 2.09^{\mathrm{a}, \mathrm{A}}$ & $21.54 \pm 0.26^{\mathrm{b}, \mathrm{B}}$ \\
\hline
\end{tabular}

Different lowercase letters indicate significant differences $(p<0.05)$ between $\mathrm{pH}$ of the emulsion gels, and different capital letters indicate significant differences $(p<0.05)$ between homogenization pressures.

In a study of enzymatic hydrolysis of lactalbumin, González-Tello et al. [62] demonstrated that there was inhibition of different enzymes by increasing the amount of substrate for the reaction. They concluded that the hydrolysis of whey protein can be explained by an instantaneous and irreversible union of the enzyme with an inhibitor present in the substrate or generated by the instantaneous hydrolysis of some minor component of the protein to be hydrolyzed. This can be corroborated since this phenomenon does not occur in the IMGS-SBi where the substrate is gradually released to the intestinal phase, which is similar to what occurs during an in vivo digestion. Here, we can see how the rate of hydrolytic product release increases according to the amount of substrate that is being transferred and, therefore, the inhibition previously described for the SBg-SBi system is not present when the IMGS-SBi system is used for in vitro digestion assays.

Finally, the type of gastric motility exerted in an in vitro digestion process is fundamental for obtaining values of proteolysis much more representative than using conventional systems (stirred beaker) that may lead to the underestimation of the digestion rate, due to certain phenomena such as the inhibition of proteolytic enzymes.

\subsubsection{Influence of the $\mathrm{pH}$ of the Emulsion Gels on Intestinal Proteolysis}

For the SBg-SBi system, those samples at $\mathrm{pH} 4.0$ showed a significantly higher percentage of hydrolysis $(p<0.05)(3.0 \%$ and $4.8 \%$ at 500 and 1000 bar, respectively) than those at $\mathrm{pH} 7.0(2.4 \% / 500 \mathrm{bar}$ and $3.9 \% / 1000 \mathrm{bar})$ (Table 4$)$. As previously discussed, this can be explained as a consequence of the fact that in these latter samples the gel structure formed is more cohesive and of greater hardness, and therefore after the gastric phase, larger gel particles are still observed (Figure 5). This agrees with the results obtained by Guo and co-workers [21,63], where a higher degree of gel fragmentation was found for "soft" emulsion gels in comparison with "hard" emulsion gels after gastric digestion. In consequence, 
the attack of hydrolytic enzymes on the protein substrate during the intestinal digestion will be more difficult for gels formed at $\mathrm{pH}$ 7.0, resulting in less hydrolysis. Furthermore, possible substrate inhibition can occur as it has already been described.

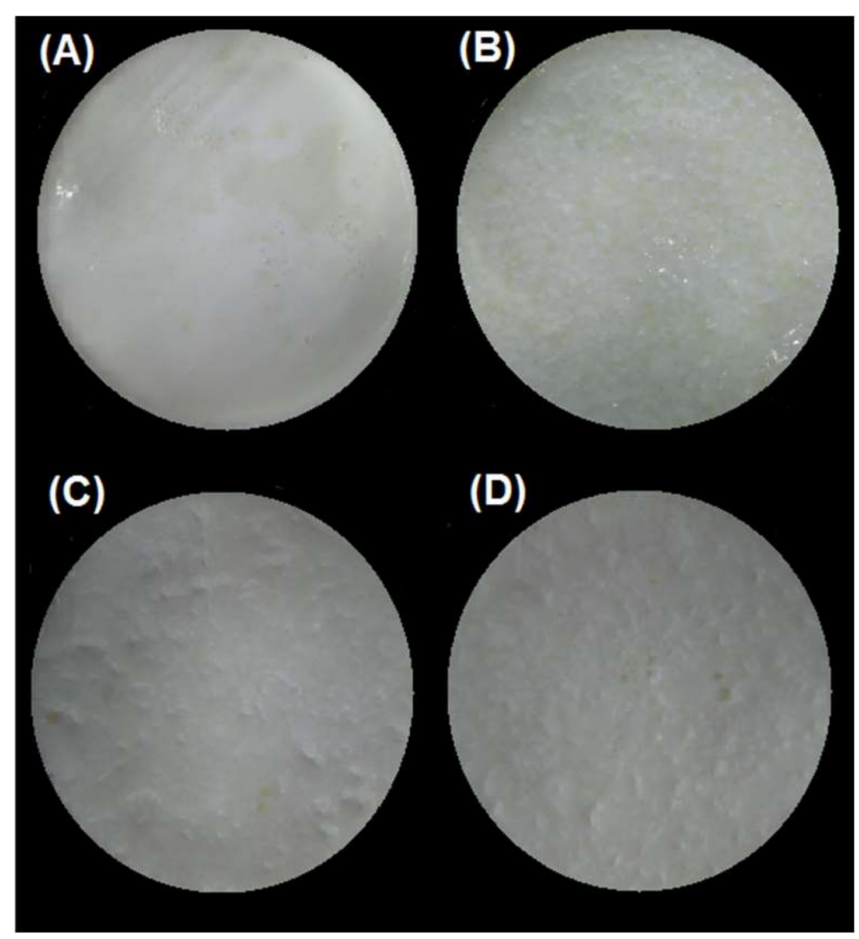

Figure 5. Images of the chyme obtained after in vitro gastric digestion in the SBg system of the different emulsion gels stabilized by WPI. (A) pH 4/500 bar, (B) pH 4/1000 bar, (C) pH 7/500 bar, and (D) $\mathrm{pH} 7 / 1000$ bar.

When analyzing the IMGS-SBi, a lag phase for all samples was observed, with times of 25 and 40 min for gels at $\mathrm{pH} 4.0$ and 7.0, respectively. As in the gastric digestion, the gels at $\mathrm{pH} 7.0$ have a higher time of disintegration induced by peristaltic forces, so the amount of protein that passes into the intestinal digestion at the beginning of gastric emptying is lower and, therefore, the time at which the proteolysis begins is later than in samples at $\mathrm{pH}$ 4.0.

For the IMGS-SBi system, significantly lower percentages of protein hydrolysis $(p<0.05)$ were obtained in the samples at $\mathrm{pH} 4.0(7.0 \%$ and $13.4 \%$ at 500 and $1000 \mathrm{bar}$, respectively), in comparison with samples at $\mathrm{pH} 7.0(15.0 \% / 500$ bar and $21.5 \% / 1000$ bar $)$ (Table 4). This difference can be attributed to the structure of the emulsion gels at $\mathrm{pH} 7.0$, since compared to smaller aggregates, the larger aggregates provide less cleavage sites for digestive enzymes due to the lower total area, thus showing lower degradation rates [64]. In addition, the tendency of the digestion kinetics differed with the $\mathrm{pH}$ of the samples, where at $\mathrm{pH} 4.0$ a plateau phase was reached at the end of the digestion time, but not so in samples at $\mathrm{pH} 7.0$ where the highest values of proteolysis were obtained without reaching a plateau. This is also related to the fact that after gastric digestion, the $\mathrm{pH} 7.0$ samples maintained small fragments of gel that went towards intestinal digestion, during which they disintegrate and release a greater amount of substrate at $80 \mathrm{~min}$. During this time, the rate of digestion increases without reaching a plateau and, therefore, said samples will need more time for a complete digestion. Figure 6 shows a representative image of the structural and physical state of the chyme formed by digesting emulsion gels at $\mathrm{pH} 7.0$ in the IMGS and emptied into the intestinal vessel for subsequent digestion. 


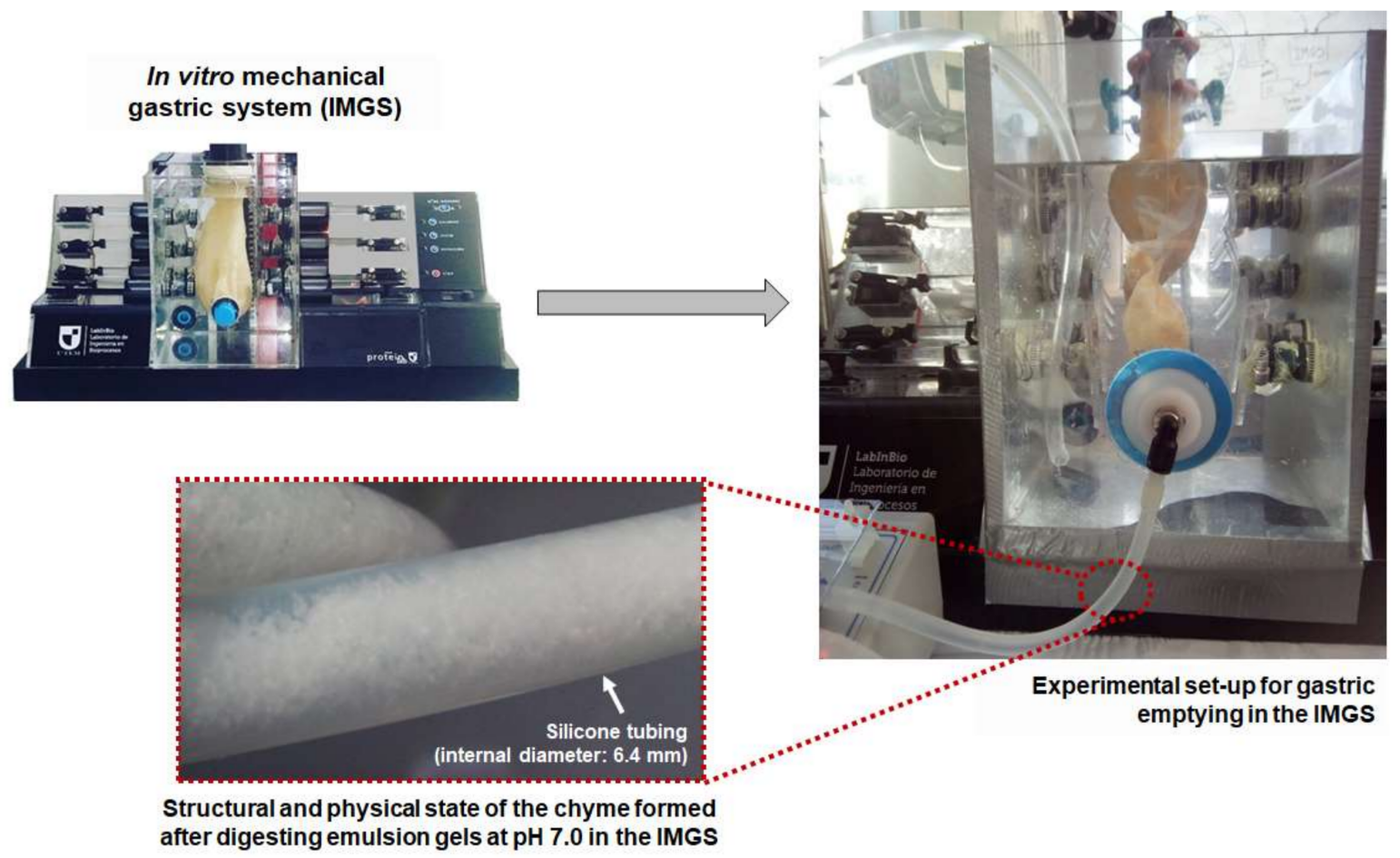

Figure 6. Representative scheme of the gastric emptying process in the IMGS and the chyme formed by digesting emulsion gels at pH 7.0 and emptied into the intestinal vessel for subsequent digestion.

3.2.4. Effect of the Type of In Vitro Gastric Digestion of Emulsion Gels on the Intestinal Lipolysis

The intestinal lipolysis of the emulsion gels was measured by the percentage of free fatty acids (\%FFA) released. This percentage was higher for gels digested in the SBg-SBi system than IMGS-SBi, as shown in Figure 7. The final extent of FFA released from gels at 500 bar using SBg-SBi was $43.9 \%$ and $42.6 \%$ for samples at pH 4.0 and 7.0, respectively, whereas these values were $28.2 \%$ and $19.4 \%$ when using IMGS-SBi (Table 4 ). Similar values were obtained for emulsion gels at 1000 bar. These findings reflect the impact that gastric motility and emptying have in food digestion, particularly for solid and semisolid matrices. Here, the type of motility exerted by the IMGS does not induce such a homogeneous chyme, since the peristaltic movements generated in a more realistic way retard the breakdown of emulsion gels (semisolid food matrices) during gastric digestion. This is because, in the human stomach, the maximum destructive force is $\sim 1.9 \mathrm{~N}$; therefore, it is difficult for this one to fragment the food particles with greater hardness into smaller pieces [63]. Then, under these conditions, the size of the pieces of emulsion gel that pass to the intestinal digestion is larger than in the conditions granted by the SBg system, where there is a more homogeneous mixture, so that there is limited access of the enzymes to the surface of oil droplets, decreasing the rate of the release of fatty acids in these samples. Since the rate of lipolysis is controlled by the interfacial area available for the binding of lipase and pancreatin and not by the amount of these [65], lipid digestion can be modulated by designing the structure of the gel around the oil droplets [66]. 

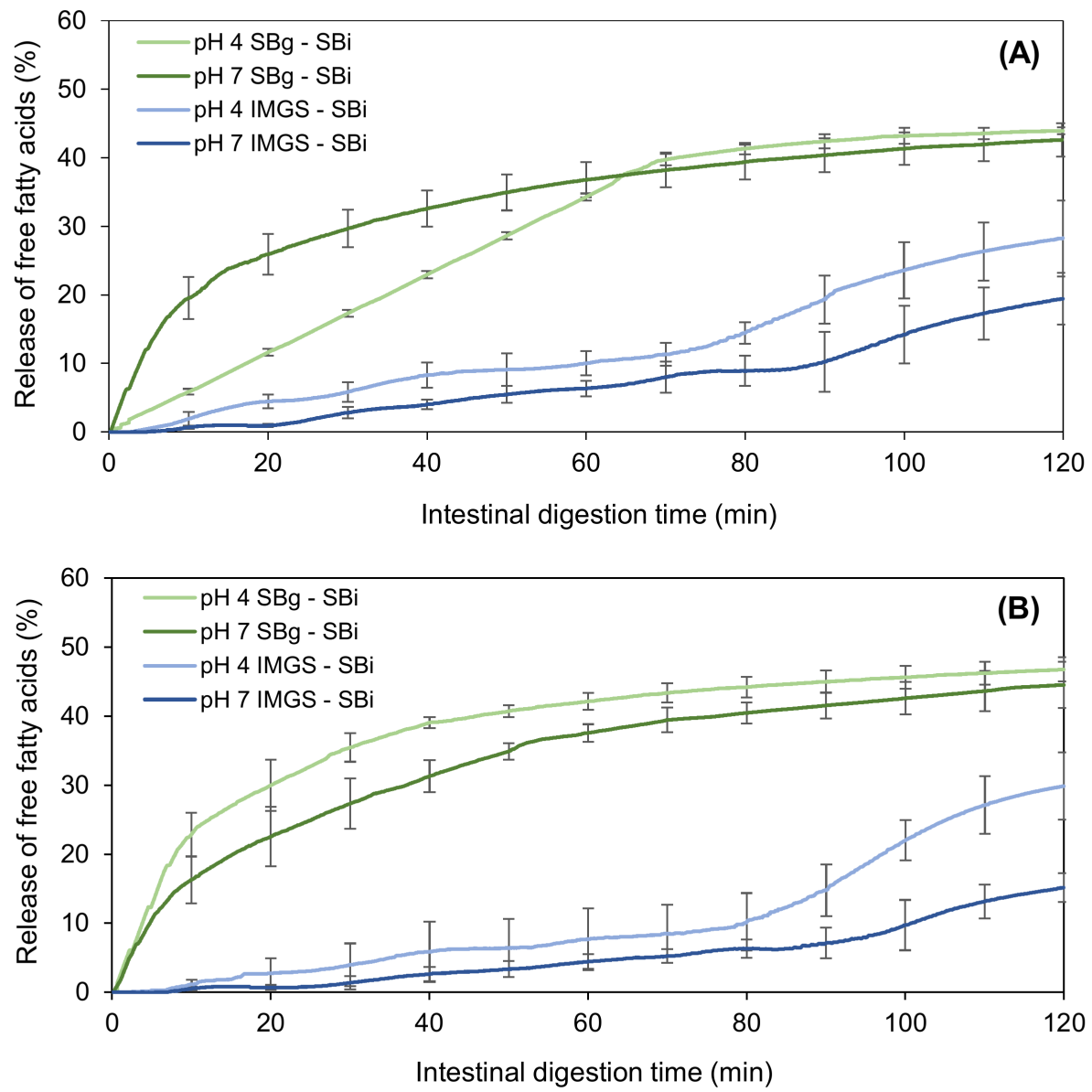

Figure 7. Kinetics of in vitro intestinal lipolysis using the systems IMGS-SBi and SBg-SBi for emulsion gels stabilized by WPI and fabricated at 500 bar (A) and 1000 bar (B).

In addition, the shape of the lipolysis kinetics obtained (Figure 7) agrees with those found for intestinal proteolysis (Figure 4), when comparing both gastric digestion methodologies (SBg vs. IMGS) and subsequent SBi. Thus, when digesting in the IMGS, which involves a mechanism of gastric emptying, the amount of chyme that passes into the intestinal phase is limited, so that the enzymes have less substrate to hydrolyze, resulting in a low rate of FFA release. The latter causes the plateau not to be generated during the $2 \mathrm{~h}$ of digestion, requiring a longer time for a complete digestion. This last resembles the kinetics of digestion studied by Barros and co-workers [13], where the lipolysis of WPI-stabilized $\mathrm{O} / \mathrm{W}$ emulsions was analyzed, which, although it was higher in the IMGS compared to the SBg system, it did not achieve a definitive plateau at the end of the digestion. This has been evidenced by in vivo studies of solid foods (e.g., rice), where at $3 \mathrm{~h}$ of digestion, $60 \%$ of the dry solids were obtained in the gastric emptying, so a longer time is needed for a gastric digestion of all the content [5]. The same phenomenon was observed in previous in vitro digestion studies of emulsions based on WPI and soybean oil. On the one hand, in the case of emulsions with palm, sunflower and linseed oil, it is only after $200 \mathrm{~min}$ of intestinal digestion that a decrease in the rate of fatty acids release is observed $[67,68]$. Lipolysis kinetics of all samples digested in the SBg-SBi system do not present a lag phase during intestinal digestion. This indicates that an enzymatic attack occurs immediately after starting the intestinal phase. This could be justified by the existence of proteolysis during gastric digestion, where the whey proteins that stabilized the $\mathrm{O} / \mathrm{W}$ emulsion were exposed to an enzymatic attack by pepsin. Consequently, the stabilizing action of WPI in the emulsion could be altered during gastric digestion, which impacted the subsequent intestinal lipolysis by facilitating the access of lipolytic enzymes to their substrate, attacking them instantaneously. 


\subsubsection{Influence of $\mathrm{pH}$ of Emulsion Gels on Lipid Digestion}

The final extent of FFA generated after intestinal digestion in the SBg-SBi system did not show significant differences $(p>0.05)$ with the $\mathrm{pH}$ of the gels, reaching a value of $\sim 43.0 \%$ FFA (Figure 7 ; Table 4). When testing in SBg-SBi, a linear rate of lipolysis during the first 65 min of digestion of emulsion gels at $\mathrm{pH} 4.0$ and 500 bar is observed, always with a released \%FFA that is lower than the $\mathrm{pH} 7.0^{\prime} \mathrm{s}$ gel. After that time, a plateau is reached, which for gels at $\mathrm{pH} 7.0$ this equilibrium stage occurs at $45 \mathrm{~min}$. The result obtained for emulsion gels at $\mathrm{pH} 4.0 / 500$ bar shows that during gastric digestion, this sample behaved similar to a liquid emulsion (Figure 5), even when it entered the oral phase as an emulsion gel. Therefore, this sample forms a homogeneous and stable matrix, and although there is a greater interfacial area, pepsin action is difficult. This is corroborated with the results of proteolysis for this sample, where less protein hydrolysis was observed. This implies a greater amount of non-hydrolyzed proteins, thus allowing the lipids to be less exposed to an enzymatic attack and also the proteolytic products of the protein to maintain their potential action as a surfactant.

In the case of the kinetics obtained in the IMGS-SBi, it is observed that the four samples under study followed a similar trend during intestinal digestion, presenting a lag phase until approximately $5 \mathrm{~min}$. This is because when gastric emptying in the IMGS begins, the chyme transported to SBi is a liquid with little substrate. Given that during the first minutes the gel disintegration is slow, the available amount of lipids for intestinal hydrolysis is consequently low, resulting in the presence of this lag phase. The digestion trends for these samples did not show significant differences $(p>0.05)$ until the $80 \mathrm{~min}$ of digestion, at which time those samples of $\mathrm{pH} 4.0$ began to increase their rate of digestion with respect to the samples of $\mathrm{pH} 7.0$.

The final \%FFA obtained in IMGS-SBi is considerably affected by $\mathrm{pH}$, with values of $29.1 \%$ and $17.2 \%$ for $\mathrm{pH} 4.0$ and 7.0 , respectively (Table 4 ). This difference is due to how the structure of gel was affected by the $\mathrm{pH}$ during its elaboration, since at a higher $\mathrm{pH}$, the internal structure of the gel is held together by disulfide bonds, which makes it less susceptible to subsequent mechanical and enzymatic action [54,55]. It is known that in the presence of pepsin, the disintegration rate of a soft gel is higher than a hard gel [63]. Consequently, it can be seen that gels made at $\mathrm{pH} 7.0$ presented values of hardness, cohesiveness and chewiness significantly higher than $\mathrm{pH} 4.0$ gels. Due to these characteristics, during gastric digestion in the IMGS, the disintegration of the structure by the peristaltic action becomes more difficult. As they have a more cohesive internal structure, the enzymatic attack by pepsin is difficult, so that the pieces of gel that finally pass through the pylorus to the intestinal phase are larger. The latter has an impact on intestinal digestion, and although the enzymatic attack of lipase and pancreatin is almost immediate, the rate of fatty acids release is low, achieving a lower final released \%FFA than gels at $\mathrm{pH} 4.0$.

Finally, the type of gastric motility and the incorporation of the gastric emptying process during digestion of emulsion gels severely impacts both the kinetics of released FFA and their final extent, which is reflected in the reduction of $\sim 47.9 \%$ between the fatty acids released by the IMGS-SBi compared to those obtained by the SBg-SBi system.

\section{Conclusions}

In this work, we studied the impact of the methodology of in vitro gastric digestion and gel structure on the in vitro intestinal proteolysis and lipolysis of emulsion gels. For this, two systems of in vitro gastric digestion were used: a system with realistic gastric peristalsis and emptying (IMGS) and a conventional system based on a stirred beaker operated at constant speed (SBg). After gastric digestion, assays of in vitro intestinal digestion were carried out in a stirred beaker (SBi). Emulsion gels stabilized by WPI were fabricated at different $\mathrm{pH}$ (4.0 and 7.0) and homogenization pressures (500 and $1000 \mathrm{bar}$ ). The textural characteristics of the gels were determined by the $\mathrm{pH}$ of their fabrication, with values of hardness and cohesiveness of $\sim 10 \mathrm{~N}$ and 0.45 , and $12 \mathrm{~N}$ and 0.87 for gels at 
$\mathrm{pH} 4.0$ and 7.0, respectively. These textural characteristics significantly impacted how the emulsion gels were digested later.

Both intestinal proteolysis and lipolysis of the emulsion gels result in a great difference when using in vitro digestion systems with different operating characteristics. The kinetics of intestinal proteolysis of the gels were markedly different among methodologies. When using the system $\mathrm{SBg}-\mathrm{SBi}$, the kinetics were similar for all samples and did not present a lag phase; however, the kinetics obtained by the methodology IMGS-SBi showed a difference in shape according to the $\mathrm{pH}$ of the sample, and a lag phase whose extent was dependent on $\mathrm{pH}$ sample. In addition, significantly higher percentages of proteolysis $(p<0.05)$ were obtained using IMGS-SBi, with values ranging from $\sim 7.0 \%$ to $21.5 \%$ with respect to SBg-SBi $(\sim 2.4-4.8 \%)$. On the other hand, the \%FFA released during the intestinal lipolysis of the gels was higher for gels digested in stirred beakers, in comparison with the system IMGS-SBi. The final extent of FFA released from gels at 500 bar using SBg-SBi was $43.9 \%$ and $42.6 \%$ for samples at $\mathrm{pH} 4.0$ and 7.0 , respectively, whereas these values were $28.2 \%$ and $19.4 \%$ when using IMGS-SBi. Similar values were obtained for emulsion gels at 1000 bar. These findings reflect the impact that gastric motility and emptying have in food digestion, particularly for solid and semisolid matrices.

It is important to understand that the results of in vitro digestion will not only depend on an initial characterization of the food matrix that will be digested (regardless of whether it is in the oral, gastric and intestinal phase), but also on how that matrix disintegrates in each stage of digestion, since the way in which this action occurs in one phase will influence the digestion behavior in the next one. In consequence, the in vitro evaluation of nutrient release should not only be conducted considering the system to be used, but also the structural changes throughout the digestion, thus being able to contribute to the rational design of foods with improved nutritional properties.

Author Contributions: Conceptualization, E.T. and R.N.Z.; methodology, E.T., R.N.Z., C.M. and M.Q.; formal analysis, E.T., R.N.Z. and C.M.; investigation, E.T., R.N.Z. and C.M.; validation, C.M. and M.Q.; resources, E.T.; data curation, E.T., R.N.Z. and C.M.; formal analysis, E.T., R.N.Z. and C.M.; writing - review and editing, E.T., R.N.Z. and C.M.; supervision, E.T. and R.N.Z.; visualization, E.T.; project administration, E.T.; funding acquisition, E.T. All authors have read and agreed to the published version of the manuscript.

Funding: This research was funded by the National Commission for Scientific and Technological Research (CONICYT Chile) through FONDECYT project 1191858.

Data Availability Statement: The data presented in this study are available on request from the corresponding author (Elizabeth Troncoso).

Conflicts of Interest: The authors declare no conflict of interest. The funders had no role in the design of the study; in the collection, analyses, or interpretation of data; in the writing of the manuscript, or in the decision to publish the results.

\section{References}

1. McClements, D.J. Future foods: A manifesto for research priorities in structural design of foods. Food Funct. 2020, 11, 1933-1945. [CrossRef]

2. Singh, H.; Gallier, S. Processing of food structures in the gastrointestinal tract and physiological responses. In Food Structures, Digestion and Health; Boland, M., Golding, M., Singh, H., Eds.; Elsevier Inc.: London, UK, 2014; pp. 51-75.

3. Dupont, D.; Alric, M.; Blanquet-Diot, S.; Bornhorst, G.; Cueva, C.; Deglaire, A.; Denis, S.; Ferrua, M.; Havenaar, R.; Lelieveld, J.; et al. Can dynamic in vitro digestion systems mimic the physiological reality? Crit. Rev. Food Sci. Nutr. 2019, 59, 1546-1562. [CrossRef]

4. Ménard, O.; Cattenoz, T.; Guillemin, H.; Souchon, I.; Deglaire, A.; Dupont, D.; Picque, D. Validation of a new in vitro dynamic system to simulate infant digestion. Food Chem. 2014, 145, 1039-1045. [CrossRef]

5. Kong, F.; Singh, R.P. A human gastric simulator (HGS) to study food digestion in human stomach. J. Food Sci. 2010, 75, E627-E635. [CrossRef]

6. Minekus, M. The TNO gastro-intestinal model (TIM). In The Impact of Food Bioactives and Health: In Vitro and Ex Vivo Models; Verhoeckx, K., Cotter, P., López, I., Kleiveland, C., Lea, T., Mackie, A., Requena, T., Swiatecka, D., Wichers, H., Eds.; Springer International Publishing AG: Cham, Switzerland, 2015; pp. 37-45. 
7. Venema, K.; Havenaar, R.; Minekus, M. Improving in vitro simulation of the stomach and intestines. In Designing Functional Foods: Measuring and Controlling Food Structure Breakdown and Nutrient Absorption; McClements, D.J., Decker, E.A., Eds.; CRC Press: Boca Raton, FL, USA, 2009; pp. 314-339.

8. Verwei, M.; Minekus, M.; Zeijdner, E.; Schilderink, R.; Havenaar, R. Evaluation of two dynamic in vitro models simulating fasted and fed state conditions in the upper gastrointestinal tract (TIM-1 and tiny-TIM) for investigating the bioaccesibility of pharmaceutical compounds from oral dosage forms. Int. J. Pharm. 2016, 498, 178-186. [CrossRef]

9. Wickham, M.J.S.; Faulks, R.M.; Mann, J.; Mandalari, G. The design, operation, and application of a Dynamic Gastric Model. Dissolution Technol. 2012, 19, 15-22. [CrossRef]

10. Kozu, H.; Nakata, Y.; Nakajima, M.; Neves, M.; Uemura, K.; Sato, S.; Kobayashi, I.; Ichikawa, S. Development of a human gastric digestion simulator equipped with peristalsis function for the direct observation and analysis of the food digestion process. Food Sci. Technol. Res. 2014, 20, 225-233. [CrossRef]

11. Chen, L.; Xu, Y.; Fan, T.; Liao, Z.; Wu, P.; Wu, X.; Chen, X.D. Gastric emptying and morphology of a "near real" in vitro human stomach model (RD-IV-HSM). J. Food Eng. 2016, 183, 1-8. [CrossRef]

12. van Aken, G. Relating food emulsion structure and composition to the way it is processed in the gastrointestinal tract and physiological responses: What are the opportunities? Food Biophys. 2010, 5, 258-283. [CrossRef]

13. Barros, L.; Retamal, C.; Torres, H.; Zúñiga, R.; Troncoso, E. Development of an in vitro mechanical gastric system (IMGS) with realistic peristalsis to assess lipid digestibility. Food Res. Int. 2016, 90, 216-225. [CrossRef]

14. Dickinson, E. Emulsion gels: The structuring of soft solids with protein-stabilized oil droplet. Food Hydrocoll. 2012, 28, 224-241. [CrossRef]

15. Sala, G.; van de Velde, F.; Cohen Stuart, M.A.; van Aken, G.A. Oil droplet release from emulsion-filled gels in relation to sensory perception. Food Hydrocoll. 2007, 21, 977-985. [CrossRef]

16. Nguyen, N.Q.; Fraser, R.J.; Bryant, L.K.; Holloway, R.H. Functional association between proximal and distal gastric motility during fasting and duodenal nutrient stimulation in humans. Neurogastroenterol. Motil. 2007, 19, 638-645. [CrossRef] [PubMed]

17. Armand, M.; Borel, P.; Pasquier, B.; Dubois, C.; Senft, M.; Andre, M.; Peyrot, J.; Salducci, J.; Lairon, D. Physicochemical characteristics of emulsions during fat digestion in human stomach and duodenum. Am. J. Physiol. Gastrointest. Liver Physiol. 1996, 271, G172-G183. [CrossRef]

18. Armand, M. Lipases and lipolysis in the human digestive tract: Where do we stand? Curr. Opin. Clin. Nutr. Metab. Care 2007, 10, 156-164. [CrossRef]

19. Bornhorst, G.M.; Singh, R.P. Gastric digestion in vivo and in vitro: How the structural aspects of food influence the digestion process. Annu Rev. Food Sci Technol. 2014, 5, 111-132. [CrossRef]

20. Li, C.; Yu, W.; Wu, P.; Chen, X.D. Current in vitro digestion systems for understanding food digestion in human upper gastrointestinal tract. Trends Food Sci. Technol. 2020, 96, 114-126. [CrossRef]

21. Guo, Q.; Ye, A.; Lad, M.; Dalgleish, D.; Singh, H. Effect of gel structure on the gastric digestion of whey protein emulsion gels. Soft Matter 2014, 10, 1214-1223. [CrossRef]

22. Mat, D.J.L.; Souchon, I.; Michon, C.; Le Feunteun, S. Gastro-intestinal in vitro digestions of protein emulsions monitored by pHstat: Influence of structural properties and interplay between proteolysis and lipolysis. Food Chem. 2020, 311, 125946. [CrossRef]

23. Gosal, W.S.; Ross-Murphy, S.B. Globular protein gelation. Curr. Opin. Colloid Interface Sci. 2000, 5, 188-194. [CrossRef]

24. Aguilera, J.M.; Rademacher, B. Protein gels. In Proteins in Food Processing; Yada, R.Y., Ed.; Woodhead Publishing Limited: Cambridge, UK, 2004; pp. 468-482.

25. Nicolai, T.; Durand, D. Controlled food protein aggregation for new functionality. Curr. Opin. Colloid Interface Sci. 2013, 18, 249-256. [CrossRef]

26. Chen, J. Food oral processing-A review. Food Hydrocoll. 2009, 23, 1-25. [CrossRef]

27. Civille, G.V.; Szczesniak, A.S. Guidelines to training a texture profile panel. J. Texture Stud. 1973, 4, 204-223. [CrossRef]

28. Zúñiga, R.N.; Kulozik, U.; Aguilera, J.M. Ultrasonic generation of aerated gelatin gels stabilized by whey protein $\beta$-lactoglobulin. Food Hydrocoll. 2011, 25, 958-967. [CrossRef]

29. Minekus, M.; Alminger, M.; Alvito, P.; Ballance, S.; Bohn, T.; Bourlieu, C.; Carriére, F.; Boutrou, R.; Corredig, M.; Dupont, D.; et al. A standarised static in vitro digestion method suitable for food-An international consensus. Food Funct. 2014, 5, 1113-1124. [CrossRef]

30. Verhoeckx, K.; Cotter, P.; López, I.; Kleiveland, C.; Lea, T.; Mackie, A.; Requena, T.; Swiatecka, D.; Wichers, H. The Impact of Food Bioactives and Health: In Vitro and Ex Vivo Models; Springer International Publishing AG: Cham, Switzerland, 2015.

31. Arancibia, C.; Miranda, M.; Matiacevich, S.; Troncoso, E. Physical properties and lipid bioavailability of nanoemulsion-based matrices with different thickening agents. Food Hydrocoll. 2017, 73, 243-254. [CrossRef]

32. Riquelme, N.; Robert, P.; Troncoso, E.; Arancibia, C. Influence of the particle size and hydrocolloid type on lipid digestion of thickened emulsions. Food Funct. 2020, 1, 5955-5964. [CrossRef]

33. Hoebler, C.; Lecannu, G.; Belleville, C.; Devauz, M.-F.; Popineau, Y.; Barry, J.-L. Development of an in vitro system simulating bucco-gastric digestion to assess the physical and chemical changes of food. Int. J. Food Sci. Nutr. 2002, 53, 389-402. [CrossRef]

34. Malagelada, J.R.; Longstreth, G.F.; Summerskill, W.H.J.; Go, V.L.W. Measurement of gastric functions during digestion of ordinary solid meals in man. Gastroenterology 1976, 70, 203-210. [CrossRef] 
35. Krul, C.; Luiten-Schuite, A.; Baan, R.; Verhagen, H.; Mohn, G.; Feron, V.; Havenaar, R. Application of a dynamic in vitro gastrointestinal tract model to study the availability of food mutagens, using heterocyclic aromatic amines as model compounds. Food Chem. Toxicol. 2000, 38, 783-792. [CrossRef]

36. Versantvoort, C.H.M.; Van de Kamp, E.; Rompelberg, C.J.M. Development of an In Vitro Digestion Model to Determine the Bioaccessibility of Contaminants from Food. RIVM Report 320102002/2004. National Institute for Public Health and the Environment: Bilthoven, The Netherlands, 2004. Available online: http:/www.rivm.nl/en/ (accessed on 2 February 2021).

37. Marciani, L.; Gowland, P.A.; Fillery-Travis, A.; Manoj, P.; Wright, J.; Smith, A.; Young, P.; Moore, R.; Spiller, R.C. Assessment of antral grinding of a model solid meal with echo-planar imaging. Am. J. Physiol. Gastrointest. Liver Physiol. 2001, 280, G844-G849. [CrossRef]

38. Schulze, K. Imaging and modeling of digestion in the stomach and the duodenum. Neurogastroenterol. Motil. 2006, 18, 172-183. [CrossRef] [PubMed]

39. Kong, F.; Singh, R.P. Disintegration of solid foods in human stomach. J. Food Sci. 2008, 73, R67-R80. [CrossRef] [PubMed]

40. Vassallo, M.J.; Camilleri, M.; Prather, C.M.; Hanson, R.B.; Thomforde, G.M. Measurement of axial forces during emptying from the human stomach. Am. J. Physiol. Gastrointest. Liver Physiol. 1992, 263, G230-G239. [CrossRef] [PubMed]

41. Elmslie, R.G.; White, T.T.; Magee, D.F. Observation on pancreatic function in eight patients with controlled pancreatic fistulas including a review of the literature. Ann. Surg. 1964, 160, 937-949. [CrossRef] [PubMed]

42. Ekmekcioglu, C. A physiological approach for preparing and conducting intestinal bioavailability studies using experimental systems. Food Chem. 2002, 76, 225-230. [CrossRef]

43. Perez de la Cruz Moreno, M.; Oth, M.; Deferme, S.; Lammert, F.; Tack, J.; Dressman, J.; Augustijns, P. Characterization of fasted-state human intestinal fluids collected from duodenum and jejunum. J. Pharm. Pharmacol. 2006, 58, 1079-1089. [CrossRef]

44. Ulleberg, E.K.; Comi, I.; Holm, H.; Herud, E.B.; Jacobsen, M.; Vegarud, G.E. Human gastrointestinal juices intended for use in in vitro digestion models. Food Dig. 2011, 2, 52-61. [CrossRef]

45. Mat, D.J.L.; Le Feunteun, S.; Michon, C.; Souchon, I. In vitro digestion of foods using pH-stat and the INFOGEST protocol: Impact of matrix structure on digestion kinetics of macronutrients, proteins and lipids. Food Res. Int. 2016, 88, 226-233. [CrossRef]

46. Adler-Nissen, J. Enzymic Hydrolysis of Food Proteins; Elsevier Applied Science Publishers: London, UK, 1986 ; pp. 365-404.

47. Spellman, D.; McEvoy, E.; O'Cuinn, G.; FitzGerald, R.J. Proteinase and exopeptidase hydrolysis of whey protein: Comparison of the TNBS, OPA and pH stat methods for quantification of degree of hydrolysis. Int. Dairy J. 2003, 13, 447-453. [CrossRef]

48. Márquez, M.C.; Vázquez, M.A. Modeling of enzymatic protein hydrolysis. Process. Biochem. 1999, 35, 111-117. [CrossRef]

49. Cheng, Q.; McClements, D.J. Formation of nanoemulsions stabilized by model food-grade emulsifiers using high-pressure homogenization: Factors affecting particle size. Food Hidrocoll. 2011, 25, 1000-1008.

50. Berton-Carabin, C.C.; Sagis, L.; Schroën, K. Formation, structure, and functionality of interfacial layers in food emulsions. Annu Rev. Food Sci. Technol. 2018, 9, 551-587. [CrossRef]

51. Dalgleish, D.G. Food emulsions-Their structures and structure-forming properties. Food Hydrocoll. 2006, 20, 415-422. [CrossRef]

52. McClements, D. Food Emulsions: Principles, Practices and Techniques, 2nd ed.; CRC Press: Boca Raton, FL, USA, 2005; pp. 245-372.

53. Hoeller, S.; Sperger, A.; Valenta, C. Lecithin based nanoemulsions: A comparative study of the influence of non-ionic surfactants and the cationic phytosphingosine on physicochemical behaviour and skin permeation. Int J. Pharm. 2009, 370, 181-186. [CrossRef]

54. Ramos, O.L.; Pereira, R.N.; Martins, A.; Rodrigues, R.; Fuciños, C.; Teixeira, J.A.; Pastrana, L.; Malcata, F.X.; Vicente, A.A. Design of whey protein nanostructures for incorporation and reléase of nutraceutical compounds in foods. Crit. Rev. Food Sci. Nutr. 2017, 57, 1377-1393. [CrossRef]

55. Ryan, K.N.; Zhong, Q.; Foegeding, E.A. Use of whey protein soluble aggregates for thermal stability-A hypothesis paper. J. Food Sci. 2013, 78, R1105-R1115. [CrossRef]

56. Tang, Q.; McCarthy, O.J.; Munro, P.A. Effect of $\mathrm{pH}$ on whey protein concentrate gel properties: Comparisons between small deformation dynamic) and large deformation (failure) testing. J. Texture Stud. 1995, 26, 255-272. [CrossRef]

57. Langton, M.; Hermansson, A.M. Fine-stranded and particulate gels of $\beta$-lactoglobulin and whey protein at varying $\mathrm{pH}$. Food Hydrocoll. 1992, 5, 523-539. [CrossRef]

58. Bansal, N.; Drake, M.A.; Piraino, P.; Broe, M.L.; Harboe, M.; Fox, P.F.; McSweeney, P.L.H. Suitability of recombinant camel (Camelus dromedarius) chymosin as a coagulant for Cheddar cheese. Int. Dairy J. 2009, 19, 510-517. [CrossRef]

59. Dangin, M.; Boirie, Y.; Guillet, C.; Beaufreère, B. Influence of the protein digestion rate on protein turnover in young and elderly subjects. J. Nutr. 2002, 132, 3228S-3233S. [CrossRef] [PubMed]

60. Figueroa, O.A.; Zapata, J.E.; Gutiérrez, G.A. Modeling of the kinetics of enzymatic hydrolysis of bovine plasma proteins. Revista EIA 2012, 17, 71-84.

61. Qi, W.; He, Z. Enzymatic hydrolysis of protein: Mechanism and kinetic model. Front. Chem. China 2006, 3, 308-314. [CrossRef]

62. González-Tello, P.; Camacho, F.; Jurado, E.; Páez, M.P.; Guadix, E.M. Enzymatic hydrolysis of whey proteins. I. Kinetic model. Biotechnol. Bioeng. 1994, 44, 523-528. [CrossRef] [PubMed]

63. Guo, Q.; Ye, A.; Lad, M.; Ferrua, M.; Dalgleish, D.; Singh, H. Disintegation kinetics of food gels during gastric digestion and its role on gastric emptying: And in vitro analysis. Food Funct. 2015, 6, 756-764. [CrossRef] [PubMed]

64. Zhang, S.; Vardhanabhuti, B. Effect of initial protein concentration and $\mathrm{pH}$ on in vitro gastric digestion of heated whey proteins. Food Chem. 2014, 145, 473-480. [CrossRef] [PubMed] 
65. Lundin, L.; Golding, M.; Wooster, T.J. Understanding food structure and function in developing food for appetite control. Nutr. Diet. 2008, 65, S79-S85. [CrossRef]

66. Guo, Q.; Ye, A.; Lad, M.; Dalgleish, D.; Singh, H. Impact of colloidal structure of gastric digesta on in-vitro intestinal digestion of whey protein emulsion gels. Food Hydrocoll. 2016, 54, 255-265. [CrossRef]

67. Ye, Z.; Li, R.; Cao, C.; Xu, Y.J.; Cao, P.; Li, Q.; Liu, Y. Fatty acid profiles of typical dietary lipids after gastrointestinal digestion and absorbtion: A combination study between in-vitro and in-vivo. Food. Chem. 2019, 280, 34-44. [CrossRef]

68. Ye, A.; Wang, X.; Lin, Q.; Han, J.; Singh, H. Dynamic gastric stability and in vitro lipid digestion of whey-protein-stabilised emulsions: Effect of heat treatment. Food Chem. 2020, 318, 126463. [CrossRef] 